\title{
Design of Liquid Waste Aerator Control Based on Fuzzy Logic
}

\author{
I Made Mataram $^{1}$ and I Ketut Wijaya ${ }^{2}$ \\ Electrical Engineering Department, Engineering Faculty \\ Udayana University, Kampus Bukit Jimbaran \\ Badung, Indonesia 80361 \\ E-mail : mademataram@unud.ac.id
}

\begin{abstract}
Liquid waste is the result of liquid production which is no longer used, so it must be processed and managed so as not to cause pollution and decrease in environmental quality. The biological wastewater treatment system can use the services of decomposing bacteria. This performance is greatly influenced by several factors, including the amount of waste water, the level of impurities, the availability of oxygen (O2), the type of dirt and so on. Parameters used as standard control of BOD and COD liquid waste standards meet the standards. An aerator in the form of an air pump is used to disperse high-pressure air in liquid waste containing oxygen in the process of aeration effluence, so that when air rises to the surface of the water oxygen binding will occur. The operation of the aerator is generally done manually, so that there is a waste of use of electrical energy. This paper discusses the design of an aerator operating control system on waste quality standards using one input fuzzy logic controller and one output. The main component of the hardware is the Uno type Arduino microcontroller used, with the sensor input in the form of COD and output in the form of long working hours of the aerator. The results obtained indicate that the control device is able to reduce the use of electrical energy by $31.03 \%$ and can work well based on the value of small deviations and controls capable of working at a set point of 6-10 hours.
\end{abstract}

Index Terms - Aerator Control, Fuzzy Logic, Use of Electrical Energy

\section{INTRODUCTION}

Industrial and domestic production processes (households) always produce waste, one of which can be liquid waste. In order for liquid waste to have no impact on the environment a waste treatment process is needed. The Waste Water Treatment Plant (WWTP) in the Suwung area uses an aeration pond system and sedimentation pond. The aeration system is used with the intention of reducing the need for land area and increasing the processing process to be faster while eliminating odors due to imperfect oxidation processes.

The aeration process as a producer of oxygen in the form of air froth mixed with water is an aerobic process of BOD (Biological Oxygen Demand) and COD (Chemical Oxygen Demand) reduction. Based on preliminary research data, the WWTP Suwung aerator is still operated manually for 11 hours per day. Operation of an aerator that is not suitable causes the use of electric power to be wasteful To meet the oxygen requirements that are in accordance with the characteristics of the treated waste input, intelligent arrangements are required from the aerator's working time, so that the loss of electrical energy can be reduced.

The development of modern control technology using aeration control system strategies with different treatments shows that the consumption of electrical energy for treatment with controlled aeration systems is reduced by around 30\% [1]. Methods with fuzzy logic techniques can be applied by utilizing the advantages in the process of linguistic reasoning without the need for complicated mathematical models. This technology as a development for classic control strategies that have obstacles in handling nonlinear processes with the help of simulation models has proven to be a useful tool for researchers to evaluate algorithms in complex integrated environments [2]. Based on the description of the background above, in this study we will design a smart way arrangement with the output of the length of time (hours) of aerator work and liquid waste characteristic input (BOD \& COD) based on fuzzy logic. The specific objective of this study is to make a liquid waste aerator control device based on fuzzy logic by setting the length of time (hours) of the aerator operation to work according to the characteristics of the waste input (BOD \& COD) by minimizing electrical energy usage but still keeping the waste at a safe limit.

Research on industrial wastewater treatment with an aeration process shows the most maximum bacterial growth occurs with an 8-hour aeration time [3]. An expert arrangement system based on fuzzy logic rules was developed by Alper KAYA [4] and Doaa M. Atia [5] for the 
diagnosis and control of a wastewater treatment plant designed theoretically to obtain research results that although there are various types of controlling several different methods such as systems on / off and controlling with proportional integrative derivatives (PID), it turns out to be the easiest and the most effective method is accepted as the fuzzy logic control method. Research conducted by Lisa Harrington et al. [6], regarding live-dead aeration control with a time interval of 3 hours can help reduce $\mathrm{BOD}$, increase $\mathrm{pH}$, maintain nitrite levels and can maintain bacterial growth in wastewater treatment. L.Amand have conducted more than 10 years of research on aeration control in case studies with more sophisticated algorithms including model-based controls with methods using simulations and in real applications can save electricity, which outperforms conventional feedforward-feedback control methods [7]. Research on the application of PI control to the aerator shows that setting the motor rotational speed on the aerator for wastewater treatment can be adjusted to the oxygen level as we want, so that the oxygen demand for breaking down pollutants on waste can be adjusted [8]. Based on research conducted by E. Nurroisah et al. [9], the effectiveness of the aeration system in liquid waste shows that the aerator can effectively reduce COD (chemical oxygen demand) and suspended solids present in liquid waste. This study presents an overview of the aeration control system with fuzzy control as a development for classic control strategies that have constraints in handling nonlinear processes with the help of simulation models proven to be a useful tool for researchers to evaluate algorithms in complex integrated environments [10].

\section{METHODS}

Research will be carried out at the Waste Water Treatment Plant (WWTP) with a research period of six four months. The data collected in this study are in the form of primary data and secondary data obtained from wastewater treatment plants, among others; data on quality standards for wastewater, daily data of BOD \& COD, volume of liquid waste, number of waste aerators, aerator specifications, aerator working time data and aerator daily energy consumption data.

The stages of research that will be carried out during the research are as follows. The preparation phase is problem identification, problem formulation and research objectives, field studies and literature studies (BOD \& COD standards, fuzzy logic based control models, Arduino Uno microcontroller sheet data). Data collection stages measure daily BOD \& COD ( $\mathrm{mg} / \mathrm{l})$, aerator data existing liquid waste, specification data for each aerator (KVA), data on the number of daily aerator work (units / days), daily data on daily aerator work hours (hours / day) and measuring daily electricity consumption (KWh / day). Data processing stage and block making aerator control diagram based on Fuzzy logic, making controller software and making hardware controller. Phase testing tool regarding the output response to input. The last stage is the analysis and conclusions about the performance of the controller (percentage error and comparison of electrical energy use manually and fuzzy logic-based controls and research weaknesses for the improvement of the next control system model.

The design block diagram of the hardware with the Arduino Uno microcontroller on the old controller operation of liquid waste aerator using COD sensor can be seen in Fig. 1. The BOD parameter is not used as an input because with the COD parameter representing the required oxygen requirements, this is based on proof expert that

$$
\mathrm{COD}=1.64 \times \mathrm{BOD}+11.36
$$

The design of software for this system can be explained as follows. The design for fuzzy logic controller uses one input and one output with the Mamdani method. The input used is in the form of COD value and the output used is in the form of the length of the aerator operation. The input consists of three quantization with the type of triangle member functions, the output also uses three quantization types of triangle member functions, and consists of 3 rules. The block diagram of the system model can be seen in Fig. 2.

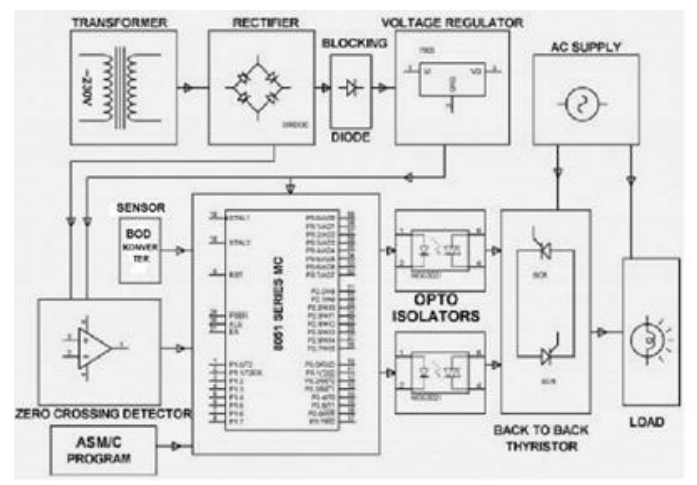

Fig. 1. Block diagram of the design of the operating controller of the work of a liquid waste aerator.
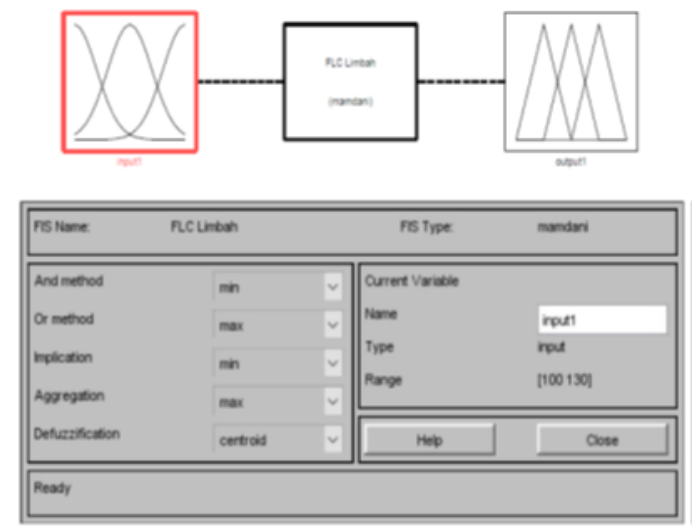

Fig. 2. Fuzzy logic controller block diagram of the operation of a liquid waste aerator. 
The input design used in the design of this system can be seen in Fig. 3.

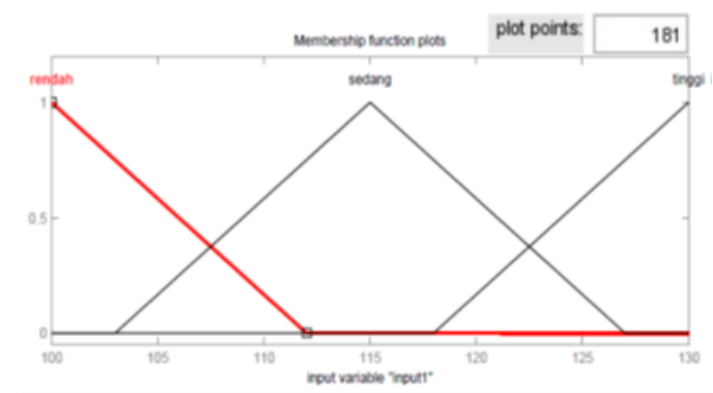

Fig. 3. Block diagram of the design of fuzzy logic controller input.

The output design used in the design of this system can be seen in Fig. 4.

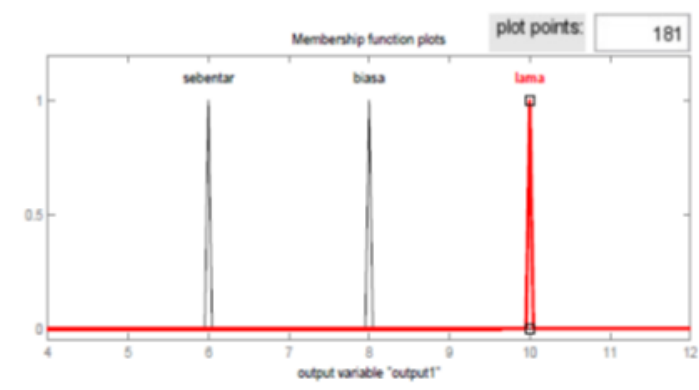

Fig. 4. Design block diagram of fuzzy logic controller output.

In the process of inferencing the system using the Mamdani method there are three basic rules used, namely as follows.

1. If (input is low) then (output is short)

2. If (input is moderate) then (output normal)

3. If (input is high) then (output is long)

Based on the fuzzy logic controller design above, the resolution of COA defuzzyfication (center of area) in the view rule is obtained as can be seen in Fig. 5, while the surface view looks like Fig. 6
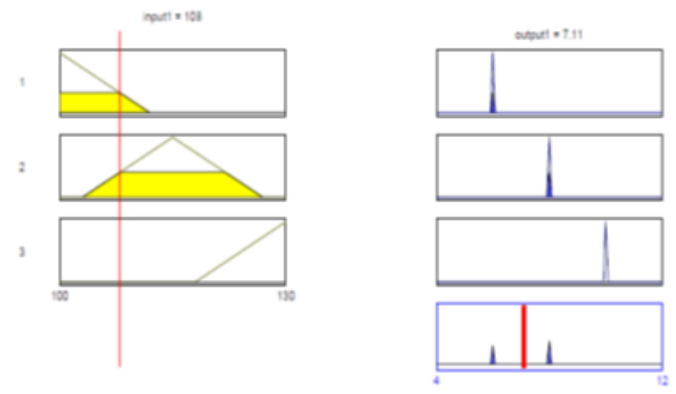

Fig. 5. Rule view of fuzzy logic controller.

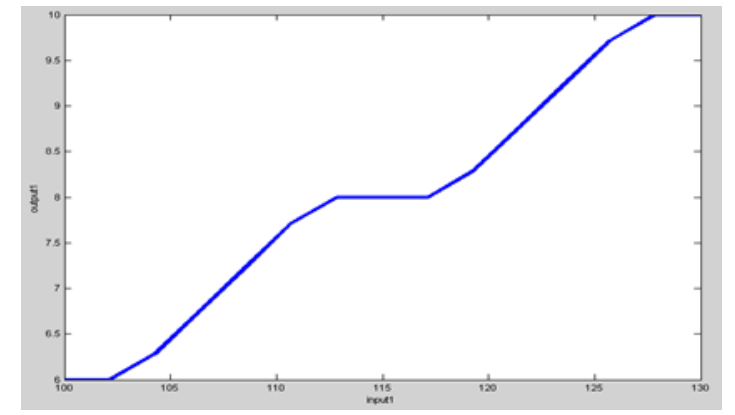

Fig. 6. Surface fuzzy logic controller.

\section{RESULT AND DISCUSSION}

Sensor Circuit Testing

The COD sensor in this prototype uses a temperature sensor that is converted to COD value. The DS18B20 digital temperature sensor is capable of reading temperatures with accuracy of 9 to 12-bits, in the range of $550 \mathrm{C}$ to $1250 \mathrm{C}$ with accuracy (+/- $0.50 \mathrm{C})$.

This sensor can respond to changes received and turn them into electrical voltages as output. Data obtained from the mercury thermometer is then compared to the output voltage of the temperature sensor. Based on this data, the value of the deviation calculated on the sensor is calculated to determine whether the sensor needs to be recalibrated.

\section{Overall Tool Testing Results}

Taking the temperature / COD in the first phase of this observation aims to determine the performance of the aerator controller before it is applied in actual conditions. Data collection is done 30 times for 3 days. The temperature data obtained comes from the values displayed in the seven segment when the data collection time is every 30 minutes. So the total amount of data retrieval is 90 temperature data / COD. The following are the results of the old output of aerator operations and the use of electrical energy in real conditions and based on fuzzy logic control

The results of measuring energy consumption are explained as follows. The average energy of _1 was 36.135 $\mathrm{KWh}$, energy _2 was $34.650 \mathrm{KWh}$, and energy_3 was $35.640 \mathrm{KWh}$ so the average total energy used was 35.475 KWh. The output results of the average operating time are equal to 8.8 hours, the average length of operation_2 for 6.8 hours and the length of operation_3 for 6.9 hours. Based on the duration of operation assuming 7 the number of aerators in operation can be calculated using electrical energy.

The results of the calculation of the average electrical energy include Energi_1 of 28,699 KWh, mean energy_2 of $22,143 \mathrm{KWh}$, and on Energi_3 of $24,468 \mathrm{KWh}$, so that the average during the study resulted in energy consumption of $22,562 \mathrm{KWh}$. Based on table 1, it can be seen that the DS18B20 sensor calibration with mercury thermometer has an error rate that does not exceed 2\% (quite small), so it can be used to measure COD water by converting temperature to COD with the same level of error / error. 
TABLE 1. TEMPERATURE SENSOR CALIBRATION DS18B20 WITH MERCURY THERMOMETER

\begin{tabular}{llcccccccccc}
\hline \multirow{2}{*}{ Parameters } & \multirow{2}{*}{ Unit } & \multicolumn{1}{c}{ Analysis results } \\
\cline { 3 - 12 } & & 1 & 2 & 3 & 4 & 5 & 6 & 7 & 8 & 9 & 10 \\
\hline Temp DS18B20 & ${ }^{\circ} \mathrm{C}$ & 28, & 29, & 30, & 31, & 32, & 33, & 34, & 35, & 36, & 37, \\
& & 4 & 5 & 3 & 5 & 5 & 6 & 5 & 3 & 5 & 5 \\
Temp mercury & ${ }^{\circ} \mathrm{C}$ & 28 & 29 & 30 & 31 & 32 & 33 & 34 & 35 & 36 & 37 \\
Conversion COD & $\mathrm{mg} / \mathrm{L}$ & 100 & 103 & 106 & 112 & 118 & 121 & 124 & 127 & 130 & 133 \\
Error & $\%$ & 1,4 & 1,7 & 1,0 & 1,6 & 1,5 & 1,8 & 1,4 & 0,8 & 1,3 & 1,3 \\
& & & & & & & & & & & \\
\hline
\end{tabular}

TABLE 2. RESULTS OF OUTPUT OF TIME OPERATION OF AERATOR AND USE OF ENERGY

\begin{tabular}{|c|c|c|c|c|c|c|c|c|c|c|c|}
\hline \multirow[b]{2}{*}{ Parameters } & \multirow{2}{*}{ Unit } & \multicolumn{4}{|c|}{ Analysis results } & \multirow[b]{2}{*}{5} & \multirow[b]{2}{*}{6} & \multirow[b]{2}{*}{7} & \multirow[b]{2}{*}{8} & \multirow[b]{2}{*}{9} & \multirow[b]{2}{*}{10} \\
\hline & & 1 & 2 & 3 & 4 & & & & & & \\
\hline COD_1 & $\mathrm{mg} / \mathrm{L}$ & 114 & 132 & 130 & 144 & 44 & 230 & 230 & 68 & 132 & 130 \\
\hline COD_2 & $\mathrm{mg} / \mathrm{L}$ & 104 & 18 & 30 & 35 & 68 & 54 & 148 & 54 & 57 & 25 \\
\hline COD_3 & $\mathrm{mg} / \mathrm{L}$ & 130 & 128 & 120 & 84 & 130 & 114 & 96 & 108 & 56 & 58 \\
\hline Time Op_1 & jam & 8 & 10 & 10 & 10 & 6 & 10 & 10 & 6 & 10 & 10 \\
\hline Time Op_2 & jam & 6,22 & 6 & 6 & 6 & 6 & 6 & 10 & 6 & 6 & 6 \\
\hline Time Op_3 & jam & 10 & 10 & 8,44 & 6 & 10 & 8 & 10 & 7,1 & 6 & 6 \\
\hline Energy_1 & KWh & 840 & 105 & 105 & 105 & 630 & 105 & 105 & 1 & 105 & 105 \\
\hline Energy_2 & KWh & 653 & 0 & 0 & 0 & 63 & 0 & 0 & 630 & 0 & 0 \\
\hline \multirow[t]{2}{*}{ Energy_3 } & KWh & 105 & 63 & 63 & 63 & 105 & 63 & 105 & 630 & 630 & 630 \\
\hline & & 0 & $\begin{array}{c}105 \\
0\end{array}$ & 886 & 630 & 0 & 840 & $\begin{array}{c}0 \\
630\end{array}$ & 746 & 630 & 630 \\
\hline
\end{tabular}

\section{CONCLUSION}

The results of the design of the control device for the working length of the aerator operation based on the fuzzy logic controller using the Arduino Uno Microcontroller, it was concluded that the tool works well and can be applied. This is based on the values of small deviations and the length of control of work in accordance with the set point which is 6-10 hours.

\section{ACKNOWLEDGMENT}

Our gratitude goes to the parties who supported the writing of this paper, among others, Electrical Engineering students, the chairman and technician of the energy conversion laboratory, Electrical Engineering, UNUD

\section{REFERENCES}

[1] Filali, A. Fayolle, Y. Peu P.. Philippe L, Nauleau F., et al.2014. Aeration control in a full-scale activated sludge wastewater treatment plant: impact onperformances, energy consumption and $\mathrm{N} 2 \mathrm{O}$ emission. ICA2013 [00941253]

[2] Amand, L. \& Carlsson, B. 2013. Optimal aeration control in a nitrifying activated sludge process. Water Research 46 (7), 21012110.

[3] Wagini,R. Karyono. Budi, A.S. 2002. Pengolahan Limbah Cair Industri Susu. Manusia dan Lingkungan vol 9 hal 23-31

[4] KAYA, A. 2006. Fuzzy design of wastewater treatment plants. Graduate Scool of Natural and Aplied Science

[5] Doaa M. Atia1, Faten H. Fahmy1, Ninet M. Ahmed1, dan Hassen T. Dorrah2. 2012. Design and Control Strategy of Diffused Air Aeration System. The Online Journal on Power and Energy Engineering OJPEE

[6] Harrington, L. Kaemmerling,C. and Leininger, J.2014. On/Off Aeration Control of an Activated Sludge Digestion System. ENV4970 Environmental Field.
[7] Amand, L. Olsson, G. dan Carlsson,B. 2013. Aeration control - a review. Water Science \& Technology $|67.11|$

[8] Tirtowiyadi,B.H. 2014. Aplikasi Kontrol Proportional Plus Integral Pada Pengaturan Kadar Oksigen (Dissolved Oxygen) Akuarium. Tugas Akhir Jurusan Teknik Elektro Fakultas Teknik Universitas Diponegoro.

[9] Nurroisah, E. Indarjo,S. Wahyuningsih,A.S. 2014. Keefektifan Aerasi Sistem Tray dan Filtrasi sebagai Penurunan Chemical Oxygen Demand an Padatan Tersuspensi pada limbah cair. Unnes Journal of Public Health.

[10] Timoty J. Ross. 1995. Fuzzy Logic With Engineering Applications. McGraw-Hill, Inc 